\title{
Long-term effects of simulated acid rain stress on a staple forest plant, Pinus massoniana Lamb: a proteomic analysis
}

\author{
Xiaoqin Wang $\cdot$ Zheng Liu $\cdot$ Li Niu • \\ Bin Fu
}

Received: 22 May 2012/Revised: 26 September 2012/ Accepted: 9 October 2012/Published online: 8 November 2012

(C) The Author(s) 2012. This article is published with open access at Springerlink.com

\begin{abstract}
At present, acid rain has become one of the top ten global environmental issues. Acid rain causes slower growth, injury, or decline of forests. Some dramatic effects on forests have been observed in south China since the late 1970s and the situation is deteriorating. We carried out a comparative proteomic analysis on Pinus massoniana Lamb, a staple tree species widely distributed in middle and south China to gain a better understanding of tree response to acid rain at molecular level. Two-year-old $P$. massoniana saplings were treated with simulated AR (SiAR) or control solution, respectively, for 8 months. The changes in total protein profile of $P$. massoniana leaves were studied using two-dimensional differential gel electrophoresis (2D-DIGE). Among the total protein spots reproducibly detected on each gel, 65 spots representing 28 proteins were identified to be differentially regulated. These proteins were annotated in various biological
\end{abstract}

Communicated by U. Luettge.

X. Wang and Z. Liu contributed equally to this work.

Electronic supplementary material The online version of this article (doi:10.1007/s00468-012-0799-z) contains supplementary material, which is available to authorized users.

\footnotetext{
X. Wang $(\bowtie)$

University of Agriculture, Beijing 102206, China

e-mail: wxqtycn@yahoo.com.cn

X. Wang $\cdot$ L. Niu $\cdot$ B. Fu

Xiamen University, Xiamen 361005, China

Z. Liu

College of Life Sciences, Hebei University,

Baoding 071002, China
}

College of Biological Science and Engineering, Beijing functions, such as photosynthesis and energy metabolism, secondary metabolism, protein stability, amino acid and nitrogen metabolism and defense. Down-regulation of four key enzymes in the Calvin cycle identified that biomass loss by SiAR was mainly due to the inhibition of carbon fixation. Primary energy metabolisms involved in sucrose biosynthesis, glycolytic pathway and Krebs cycle, etc., were also disturbed after SiAR treatment. Specifically, most of up-regulated proteins were related to secondary metabolism, protein stability and defense, suggesting that in response to SiAR stress, plants started a variety of metabolic pathways to prevent cells from damage. Different from the herbaceous plants suffering SiAR, it revealed that secondary metabolites in P. massoniana play pivotal roles against SiAR. Protemoic techniques were demonstrated a reliable and robust tool to expand our understanding of differentially expressed proteins associated with acid rain stress on P. massoniana. Functional analysis of these proteins further revealed biochemical and physiological basis of the plant in response to acid rain and would provide strategies for breeding new acid rain tolerant tree species. To our knowledge, it is the first proteome report on the forest plant suffering long-term acid rain stress.

Keywords 2D-DIGE - LC-MS/MS - Simulated acid rain stress · Pinus massoniana Lamb · Proteome

$\begin{array}{ll}\begin{array}{ll}\text { Abbreviations } \\ \text { 2D-DIGE }\end{array} & \begin{array}{l}\text { Two-dimensional differential gel } \\ \text { electrophoresis }\end{array} \\ \text { ACP } & \text { Acyl-carrier protein } \\ \text { COMT } & \text { Caffeate } O \text {-methyltransferase } \\ \text { FBPase } & \text { Fructose-bisphosphate aldolase } \\ \text { GAPDH } & \text { Glyceraldehyde-phosphate dehydrogenase }\end{array}$

Abbreviations electrophoresis

ACP Acyl-carrier protein

COMT Caffeate $O$-methyltransferase

GAPDH Glyceraldehyde-phosphate dehydrogenase 
GS Glutamate-ammonia ligase (glutamine synthetase)

HDR Type 2 1-hydroxy-2-methyl-2-(E)-butenyl-4phosphate reductase

HSP Heat shock protein

ICDH Isocitrate dehydrogenase

JA Jasmonic acid

MDH Malate dehydrogenase

MDHAR Monodehydroascorbate reductase

OEE Oxygen evolving enhancer protein

PCBER Phenylcoumaran benzylic ether reductase

PGK Phosphoglycerate kinase

PPDBR Phenylpropenal double-bond reductase

PRK Phosphoribulokinase

ROS Reactive oxygen species

RuBP Ribulose-1,5-bisphosphate

SBPase Sedoheptulose-1,7-bisphosphatase

SiAR Simulated acid rain

\section{Introduction}

Acid rain emerged as an important environmental problem in China in the late 1970s. The frequency of acid rain has kept increasing since then. Acid rain, as an abiotic stress, has devastating effects on all plants: it strips the protective wax from leaves, allowing leaves to desiccate and die (Percy and Baker 1990). Acid rain also induces changes in the cellular biochemistry and physiology of the whole plant. Biological effects of acid rain on plants are numerous and complex, and include visible symptoms of injury (chlorosis and necrosis) and invisible effects such as reduced photosynthesis, nutrient loss from leaves, altered water balance, variation of several enzyme activities, changes of pollen physiology and ultrastructure (Bellani et al. 1997; Van Huylenbroeck et al. 2000). It was reported that the loss of forest ecological benefits caused by acid rain exceeded 16 billion Yuan (2.4 billion dollars) per year only in 11 provinces of south China (Feng 2000). Pinus massoniana Lamb is a staple tree species of high economic value in middle and south China. Previous study has shown that under acid rain stress, the leaf area of the plant was significantly reduced, resulting in the decrease of photosynthesis. The plant growth was therefore inhibited and biomass was reduced (Huang et al. 2006).

One way to study the cellular response to acid rain on a large scale is to examine gene expression at the mRNA level using the technique such as cDNA microarrays or macroarrays. Although this method under acid stress has deepened our understanding a great deal (Ohta et al. 2005; Tamaoki et al. 2004), changes in transcriptome are not always correlated with changes in the abundance of the corresponding protein species, the key players in the cell (Chen et al. 2002; Gygi et al. 1999; MacKay et al. 2004; Tian et al. 2004). This is mainly due to post-transcriptional regulation mechanisms such as nuclear export and mRNA localization, transcript stability, translational regulation, and protein degradation (Pradet-Balade et al. 2001). Therefore, it is impossible to reliably predict protein abundance from quantitative mRNA data.

Proteomic approach is a powerful tool to study plant stress responses. A global protein expression profile can be investigated and compared using a two-dimensional gel electrophoresis (2-DE), a gel-based protein separation method coupled with protein identification by mass spectrometry (MS). Proteomics is thus evolving and playing an increasingly important role in addressing these issues. In fact, it has become a necessary and complementary approach in the post-genomic era (van Wijk 2001; Zivy and de Vienne 2000). A number of investigations revealing plant proteomes responding to different environmental cues, including cold, heat, drought, waterlogging, salinity, heavy metal, wounding, etc., have been carried out using this approach (Kosova et al. 2011). As acid rain is overwhelming around the world, especially in developing countries such as in China and it has devastating effects on forest, it is desirable to identify acid rain responsive proteins in trees through a proteomic method. This will extend our ability to improve acid rain tolerance in trees.

In the present work, we started a functional proteomic investigation of proteins that are responsive to simulated acid rain (SiAR) in P. massoniana using 2-DE and MS methods. As a result, we found 65 protein spots were differently accumulated, of which the identity of 28 proteins were established. The physiological and biochemical implications of these proteins are discussed in context of a flow of complex events occurring under SiAR stress condition. This analysis provided a view of proteome level changes caused by SiAR exposure. As a whole, this study provides the framework for the better understanding of the mechanisms that govern tree responses to acid rain induced stress by a comparative proteomic analysis. Different from short-term effects of SiAR on plants, this study, for the first time, provides the framework for the better understanding of the mechanisms that govern tree responses to long-term treatment by SiAR through a comparative proteomic analysis.

\section{Materials and methods}

Plant materials and treatment

Two-year-old saplings of $P$. massoniana were purchased from Fujian saplings company of China and were grown in 
big pots containing 61 soil each pot in green house. The average temperature of greenhouse is $23.5^{\circ} \mathrm{C} \pm 3$. The saplings were shone by natural light $\left(24^{\circ} 26^{\prime} \mathrm{N}\right.$ latitude, $118^{\circ} 0.1^{\prime} \mathrm{E}$ longitude). The saplings were treated with the solution at $\mathrm{pH} 5.6$ (control) or that at $\mathrm{pH} 3.0$ (SiAR stress) by both of spraying ( 61 solution per month, equivalent to moderate rain and the actual size of droplets is about $1.5 \mathrm{~mm}$ ) and watering (8 1 per pot per month). The solutions ( $\mathrm{pH} 5.6$ and $\mathrm{pH} 3.0$ ) were made by adding a mixture of $\mathrm{H}_{2} \mathrm{SO}_{4}$ and $\mathrm{HNO}_{3}$ in the ratio of 5:1. In SiAR solution (pH 3.0), the final concentrations of $\mathrm{H}_{2} \mathrm{SO}_{4}$ and $\mathrm{HNO}_{3}$ were 0.45 and $0.09 \mathrm{mM}$, respectively, which represents the average ion compositions of rainfall in south China (i.e. the total amount of SiAR treatment per month as sulfur and nitrogen were 0.063 and $0.0126 \mathrm{~mol}$, respectively). The saplings were treated continuously for 8 months. After treatment, 6 saplings were used for this study (3 saplings for control and 3 saplings for SiAR treatment). The needle leaves were harvested and frozen in liquid nitrogen and stored at $-80{ }^{\circ} \mathrm{C}$. The needle leaves that only show the damage phenotype were collected after SiAR treatment, while needle leaves of the same age from the control plants were collected as control.

\section{Chemicals}

CHAPS, urea, thoiurea, iodoacetamide, acrylamide, bisacrylamide, DTT, SDS, IPG buffer (pH3-10), Cy2, Cy3 and Cy5 $\mathrm{N}$-hydroxysuccinamide (NHS) esters were purchased from GE Healthcare Bio-Sciences AB (Uppsala, Sweden); anhydrous $N, N$-dimethylformamide (DMF), lysine, ammonium acid carbonate were purchased from Sigma-Aldrich (St Louis, MO, USA). Agarose (Lowmelting), acetonitrile, sequencing grade modified trypsin were purchased from Promega (Madison, WI, USA).

\section{Protein extraction}

Plant tissue $(1 \mathrm{~g})$ was grounded into fine powder in liquid nitrogen and homogenized on ice for $10 \mathrm{~min}$ with $3 \mathrm{ml}$ icecold homogenization buffer $(250 \mathrm{mM}$ sucrose, $20 \mathrm{mM}$ Tris-HCl pH 7.5, $10 \mathrm{mM}$ EDTA, $1 \mathrm{mM}$ phenylmethylsulfonyl fluoride, $1 \mathrm{mM}$ 1,4-dithiothreitol [DTT], $1 \% \mathrm{w} / \mathrm{v}$ Triton X-100). Then an equal volume of ice-cold Tris- $\mathrm{HCl}$ (pH 7.5) saturated phenol was added, and the mixture was re-homogenized for $10 \mathrm{~min}$ on ice. After centrifugation $\left(15,000 \mathrm{~g}, 4{ }^{\circ} \mathrm{C}\right)$ for $20 \mathrm{~min}$, the phenol phase was collected and proteins were precipitated with 3 volumes of $100 \mathrm{mM}$ ammonium acetate in methanol overnight at $-20{ }^{\circ} \mathrm{C}$ followed by centrifugation with the same conditions as above. The pellets were rinsed 3 times with ice-cold acetone containing $13 \mathrm{mM}$ DTT and then lyophilized. The resulting pellets were dissolved in a sample buffer ( $7 \mathrm{M}$ urea, $2 \mathrm{M}$ thiourea, $4 \%$ (w/v) CHAPS, $0.5 \%$ (v/v) IPG buffer (IPG Drystrip $\mathrm{pH} 4-7), 1 \%(\mathrm{w} / \mathrm{v})$ DTT) at room temperature. Every $800 \mu \mathrm{g}$ protein powders were dissolved in a $450-\mu \mathrm{l}$ sample buffer. After centrifugation as described above, the supernatants containing proteins were used for the following experiments.

\section{Protein-cyanine dye labeling}

Cy2, Cy3, and Cy5 N-hydroxysuccinamide (NHS) esters were freshly dissolved in anhydrous $\mathrm{N}, \mathrm{N}$-dimethylformamide (DMF), respectively, to the final concentration of $400 \mathrm{pM}$ as working solutions. Control and treatment protein samples were cross-labeled with $\mathrm{Cy} 3$ or $\mathrm{Cy} 5$ dyes. An internal standard (IS) was then prepared by mixing equal amounts of protein extracts from control and treatment and the resulting mixture was labeled with $\mathrm{Cy} 2$ dye. Each labeling was carried out in duplicate. In each case the sample buffer containing $50 \mu \mathrm{g}$ of protein was labeled with $1 \mu \mathrm{l}$ of the working solution. The labeling mixture was incubated on ice in the dark for $30 \mathrm{~min}$ and also centrifuged $(12,000 \mathrm{~g})$ at room temperature for $5 \mathrm{~min}$. The reaction was terminated by adding $1 \mu \mathrm{l}$ of $10 \mathrm{mM}$ lysine and incubated on ice for $10 \mathrm{~min}$. Four mixtures were prepared, each made of the following: (1) a sample from control proteins labeled with one dye (Cy5 or Cy3); (2) a sample from treatment proteins labeled with the other dye (Cy3 or Cy5) and the internal standard. These mixtures were then used for 2-DE gels.

\section{Two-dimensional gel electrophoresis}

Two-dimensional electrophoresis was carried out as follows: the sample buffer was added to CyDyes-labeled samples $(150 \mu \mathrm{g}$ protein in total) to make up the final volume of $450 \mu \mathrm{l}$. Dry immobilized $\mathrm{pH}$ gradient strips (24 cm long, pH 4-7 linear) (GE Healthcare Amersham Bioscience, Little Chalfont, UK) were then rehydrated by loading the sample solution prepared above for $12 \mathrm{~h}$. Isoelectric focusing was conducted at $20{ }^{\circ} \mathrm{C}$ with an Ettan IPGphor system (GE Healthcare). Focusing was performed in four steps: $300 \mathrm{~V}$ for $1 \mathrm{~h}, 600 \mathrm{~V}$ for $1 \mathrm{~h}, 1,000 \mathrm{~V}$ for $1 \mathrm{~h}$, and $8,000 \mathrm{~V}$ for $6 \mathrm{~h}$. Focused strips were then equilibrated by first incubating them in an equilibration solution (6 M urea, $30 \%$ (v/v) glycerol, $2.5 \%$ (w/v) SDS, $50 \mathrm{mM}$ Tris-HCl, pH 6.8) containing $1 \%$ (w/v) DTT for $15 \mathrm{~min}$, followed by incubation in $2.5 \%(\mathrm{w} / \mathrm{v})$ iodoacetamide in the same equilibration solution for $15 \mathrm{~min}$. For the second dimension, the proteins were separated on $15 \%$ SDS polyacrylamide gels. 
Image and data analysis

After SDS-PAGE, cyanine dye-labeled proteins were visualized directly by scanning using a Typhoon 9400 imager (GE Health-care/Amersham Biosciences). The parameters were set as follows: Cy2: $520 \mathrm{Bp} 40 \mathrm{Cy} 2$, the photomultiplier tube (PMT): $500 \mathrm{~V}$; Cy3: 580 Bp30, PMT: 550 V; Cy5: 670 Bp50 Cy5, PMT: 480 V. After scanning, the gel was stained for visualization using colloidal Coomassie brilliant blue (cCBB). DeCyder 2D Software, Version 6.5 (Amersham Bioscience) was used for protein differential expression analysis. Only those spots with significant (quantitative changes more than 1.5-fold in abundance) and reproducible changes in three replicates were used for further analysis.

In-gel digestion and protein identification

Differentially displayed protein spots were manually excised from the preparative 2-D gels. In-gel digestion by trypsin and analysis by LC-MS/MS were performed according to Wang et al. (2010). The acquired MS/MS spectra were searched against the NCBI protein database using the TurboSEQUEST program in the BioWorks 3.1 software suite (Thermo). The cross-species searching was performed due to the unavailability of full $P$. massoniana genome. An accepted SEQUEST result had a Cn score of at least 0.1 (regardless of charge state). Peptides with a +1 charge state were accepted if they were fully tryptic digested and had a cross correlation $\left(X_{\text {corr }}\right)$ of at least 1.9. Peptides with a +2 charge state were accepted if they had an $X_{\text {corr }} \geq 2$.2. Peptides with a +3 charge state were accepted if they had an $X_{\text {corr }} \geq 3.75$. The peptides were then blasted against NCBI database and the proteins were identified according to the highest score of peptide alignment.

\section{Results}

Effects of SiAR treatment on leaves of P. massoniana

At the first 4 monthes of SiAR treatment to P. massoniana, there was no significant change of leaf morphology. Thereafter, it exhibited injury symptoms on leaves. Foliar injury first occurred on young needle tips, turning withered and yellow. However, such injuries were not observed on sapling stem and branches. Leaves that were just stretching entirely were more vulnerable than old leaves. With the increase of SiAR sprinkling, wounded spots gradually expand from the tip to the base. In general, there was a cumulative damage on $P$. massoniana by SiAR. With the treatment time increasing, the plants suffered heavier losses with significant area of yellowing and wilting on the leaf tip (Fig. 1). These are consistent with the observations by Huang et al. (2006).

Proteome profile of P. massoniana and its changes under SiAR stress

Total proteome was extracted from P. massoniana leaves following treatment at $\mathrm{pH} 5.6$ (control) or $\mathrm{pH} 3.0$ (SiAR stress) and resolved by 2-DE. In order to get credible results, the experiments (from plants' treatment to 2-DE) were carried out in four replicates of each sample. Only those protein spots that could be detected in at all four replicated gels were considered as real protein spots. Gels from the different experiments had high reproducibility.
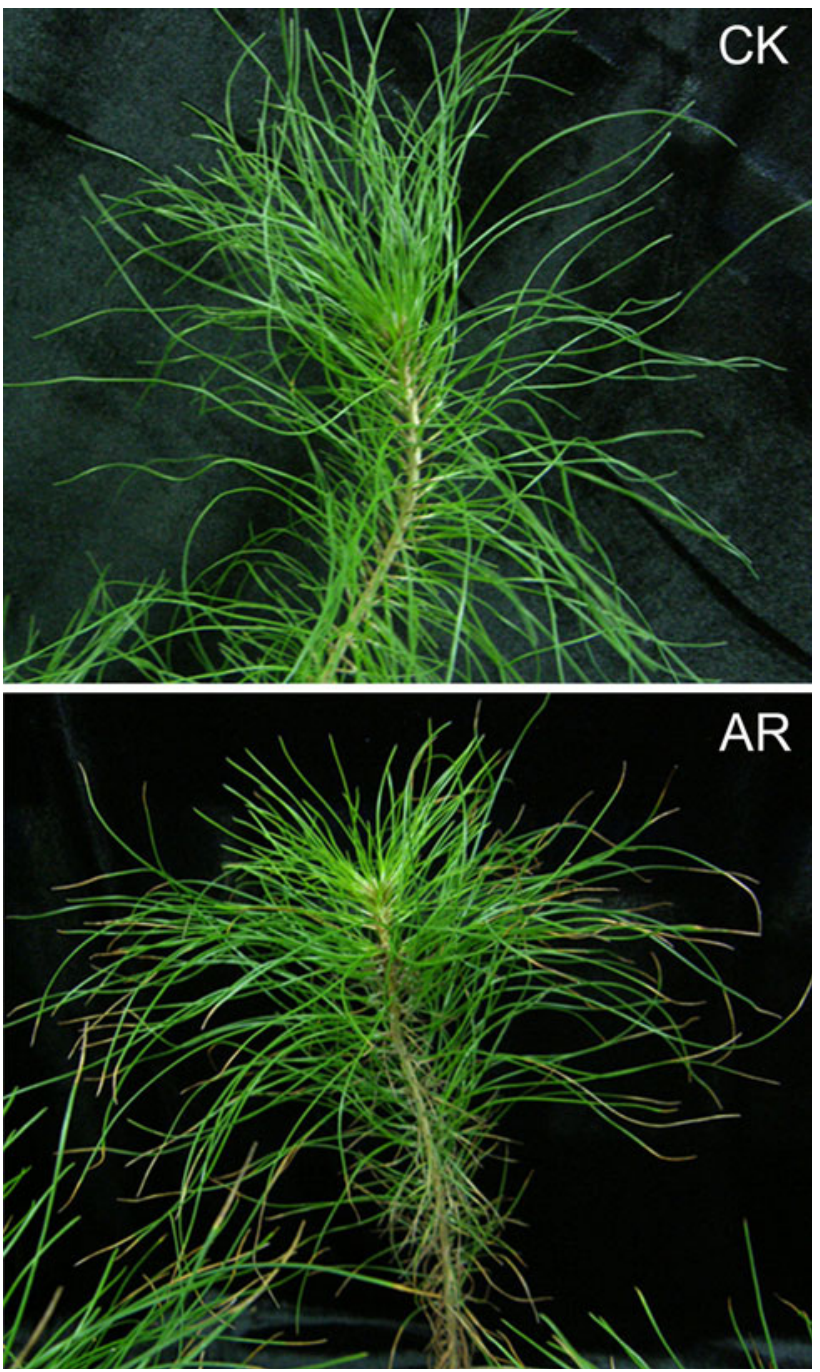

Fig. 1 Effect of simulated acid rain (SiAR) on leaves. $C K$ leaves treated by control water, $A R$ leaves treated by simulated acid rain (SiAR). It was found that when treated by SiAR, the leaf tips showed yellow wilt 
Representative gels from the control and treatment plants are shown in Fig. 2.

Comparative analysis of the 2-DE maps of the plants treated by control and SiAR was performed using DeCyder 2D Software. Proteome was established over the isoelectric point (pI) range from 4 to 7 . In general, the proteome profiles were very similar. 65 protein spots changed in abundance more than 1.5-fold evaluated by ANOVA analysis at 0.05 levels after treatment.

Plant response toward SiAR stress is a complicated physiological process in which many biochemical processes might be initiated or inhibited. So it is reasonable to expect changes in the abundance of many proteins; however, only 65 from more than 1,000 protein spots changed intensively by more than 1.5 -fold. This surprising stability of the proteome under SiAR stress suggests that those 65 protein spots that did change are worthy of further attention for elucidating the mechanism of acid tolerance. Further inspection of the gel patterns revealed that the MW and/or $\mathrm{pI}$ values of the spots differed from their theoretical values. This could be due to post-translational modifications that alter protein MW and/or pI. An alternative simple reason for difference of pI value would be due to cross-species identification because the proteins identified are not exactly the same as the one in the database. The change of a few amino acids could have a huge impact on pI. However, for MW the differences are generally small.

Protein identification and functional categorization

To categorically identify the nature of proteins involved in SiAR tolerance, we used a liquid chromatography-tandem mass spectrometry (LCMS/MS) approach. Of all the 65 differentially regulated protein spots, 28 proteins were identified (13 down-regulated and 15 up-regulated proteins) (Table 1) and functionally classified according to their homology with other proteins based on a blast search due to a complete annotated sequence of $P$. massoniana genome is not yet available. These SiAR responsive proteins identified were found to be involved in diverse biological processes, covering photosynthesis and energy metabolism (53\%), secondary metabolism (18\%), protein stability (14\%), amino acid and nitrogen metabolism (11\%), defense (4\%) (Table 1; Fig. 3).

The most abundant proteins which were differentially regulated after SiAR treatment belong to photosynthesis

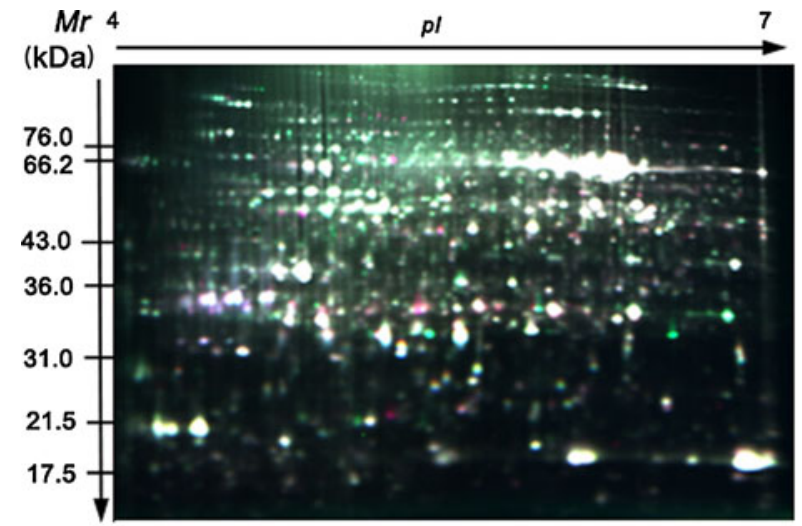

$\mathrm{IS}+\mathrm{CK}+\mathrm{AR}$

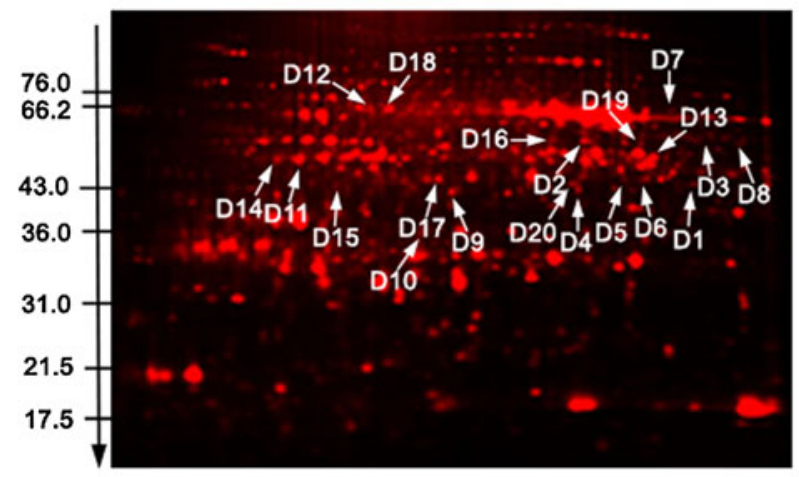

CK

Fig. 2 2-DE of total protein extracts from control (CK) and simulated acid rain (SiAR) treatment of P. massoniana Lamb leaves. Down-regulated proteins (spots. D1-D20) were indicated in the

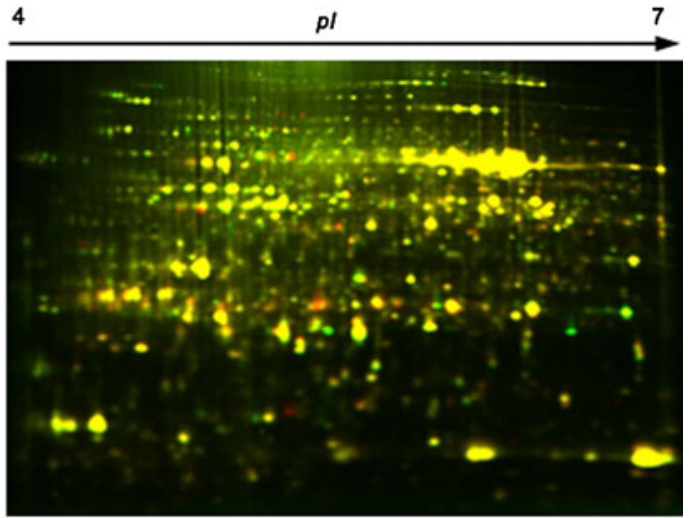

$\mathrm{CK}+\mathrm{AR}$

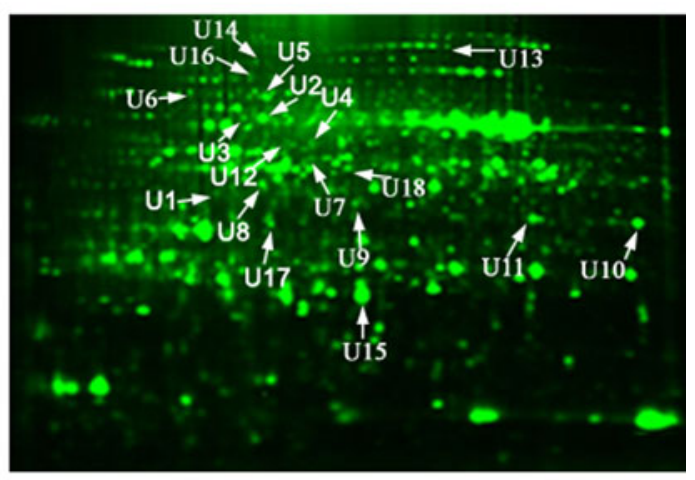

AR

image of control water treatment Up-regulated proteins (spots. U1U18) were indicated in the image of simulated acid rain (SiAR) treatment 
Table 1 Identification of AR stress-responsive proteins in P. massoniana

\begin{tabular}{|c|c|c|c|c|c|c|c|c|}
\hline Metabolic group & Spot no. & $\begin{array}{l}\text { Theor./exp. } \\
\text { mass (kDa) }\end{array}$ & $\begin{array}{l}\text { Theor./ } \\
\text { exp. pI }\end{array}$ & $\begin{array}{l}\text { Accession } \\
\text { no. }\end{array}$ & NMP & $\mathrm{SC}(\%)$ & Description & Species \\
\hline \multirow{24}{*}{$\begin{array}{l}\text { Photosynthesis and } \\
\text { energy metabolism }\end{array}$} & D1 & $51.79 / 45.36$ & $6.09 / 6.61$ & gi86559824 & 3 & 6.65 & Rubisco large subunit & P. nigra \\
\hline & D2 & $51.78 / 54.33$ & $6.09 / 6.14$ & gi86559818 & 12 & 27.90 & Rubisco large subunit & P. heldreichii \\
\hline & D3 & $51.79 / 55.49$ & $6.09 / 6.68$ & gi86559824 & 6 & 14.81 & Rubisco large subunit & P. nigra \\
\hline & D4 & $51.68 / 44.40$ & $6.09 / 6.11$ & gi86559796 & 2 & 4.29 & Rubisco large subunit & P. bhutanica \\
\hline & D5 & $51.68 / 46.82$ & $6.09 / 6.30$ & gi86559796 & 11 & 25.54 & Rubisco large subunit & P. bhutanica \\
\hline & D6 & $51.77 / 46.63$ & $6.09 / 6.41$ & gi86559818 & 9 & 19.31 & Rubisco large subunit & P. heldreichii \\
\hline & D7 & $51.68 / 61.71$ & $6.09 / 6.52$ & gi86559796 & 15 & 33.05 & Rubisco large subunit & P. bhutanica \\
\hline & D8 & $51.68 / 54.10$ & $6.09 / 6.82$ & gi86559796 & 6 & 12.66 & Rubisco large subunit & P. bhutanica \\
\hline & D9 & $42.96 / 43.93$ & $6.39 / 5.57$ & gi227464396 & 3 & 12.31 & $\begin{array}{l}\text { Fructose-bisphosphate } \\
\text { aldolase }\end{array}$ & M. sativa \\
\hline & D10 & $42.09 / 39.93$ & $6.17 / 5.42$ & gi300681420 & 1 & 3.82 & $\begin{array}{l}\text { Sedoheptulose-1,7- } \\
\text { bisphosphatase }\end{array}$ & T. aestivum \\
\hline & D11 & $39.03 / 50.76$ & $5.41 / 4.92$ & gi1885326 & 9 & 40.91 & Phosphoribulokinase & P. sativum \\
\hline & D12 & $48.49 / 62.77$ & $5.72 / 5.22$ & gi28190293 & 3 & 9.65 & Sucrose-phosphatase & P. taeda \\
\hline & D13 & $44.23 / 50.98$ & $7.54 / 6.43$ & gi435103 & 8 & 27.74 & $\begin{array}{l}\text { Glyceraldehyde- } \\
\text { phosphate } \\
\text { dehydrogenase }\end{array}$ & P. sylvestris \\
\hline & D14 & $39.96 / 50.76$ & $5.46 / 4.81$ & gi162458813 & 6 & 22.73 & $\begin{array}{l}\text { Pyruvate dehydrogenase } \\
\text { E1 beta subunit } \\
\text { isoform }\end{array}$ & Z. mays \\
\hline & D15 & $52.86 / 45.84$ & $8.83 / 5.08$ & gi332591479 & 5 & 16.37 & $\begin{array}{l}\text { Phosphoglycerate } \\
\text { kinase } 1\end{array}$ & P. pinaster \\
\hline & D16 & $46.65 / 55.26$ & $6.35 / 5.99$ & gi37962884 & 8 & 24.46 & $\begin{array}{l}\text { NADP-isocitrate } \\
\text { dehydrogenase }\end{array}$ & P. pinaster \\
\hline & U1 & $41.44 / 44.76$ & $7.72 / 4.99$ & gi317373789 & 1 & 4.85 & Enoyl-ACP reductase & H. апnиus \\
\hline & $\mathrm{U} 2$ & $45.91 / 62.04$ & $5.33 / 5.35$ & gi56784991 & 2 & 8.47 & $\begin{array}{l}\text { ATP synthase beta } \\
\text { subunit }\end{array}$ & O. sativa Japonica \\
\hline & U3 & $59.56 / 62.04$ & $5.73 / 5.08$ & gi3676296 & 9 & 23.38 & ATPase beta subunit & N. sylvestris \\
\hline & U4 & $59.51 / 56.99$ & $6.13 / 5.35$ & gi3893824 & 1 & 3.62 & ATPase beta subunit & N. sylvestris \\
\hline & U5 & $59.51 / 67.96$ & $6.13 / 5.15$ & gi3893824 & 3 & 10.83 & ATPase beta subunit & N. sylvestris \\
\hline & U6 & $11.73 / 68.98$ & $9.88 / 4.86$ & gi291461616 & 1 & 15.65 & $\begin{array}{l}\text { Granule-bound starch } \\
\text { synthase }\end{array}$ & I. batatas \\
\hline & U7 & $48.13 / 52.25$ & $5.81 / 5.18$ & gi21554349 & 2 & 3.40 & $\begin{array}{l}\text { Malate dehydrogenase } \\
\text { (NADP) }\end{array}$ & A. thaliana \\
\hline & U8 & $43.28 / 45.91$ & $5.95 / 5.17$ & gi225426948 & 1 & 3.80 & Transaldolase ToTAL2 & $V$. vinifera \\
\hline \multirow[t]{5}{*}{$\begin{array}{l}\text { Secondary } \\
\text { metabolism }\end{array}$} & D17 & $40.25 / 46.33$ & $5.80 / 5.51$ & gi56605372 & 4 & 14.56 & $\begin{array}{l}\text { Caffeate } O \text { - } \\
\text { methyltransferase }\end{array}$ & P. abies \\
\hline & U9 & $33.52 / 42.90$ & $5.76 / 5.62$ & gi3415126 & 7 & 32.79 & $\begin{array}{l}\text { Phenylcoumaran } \\
\text { benzylic ether } \\
\text { reductase PT1 }\end{array}$ & P. taeda \\
\hline & U10 & $33.29 / 43.54$ & $6.93 / 6.79$ & gi7578909 & 8 & 31.60 & $\begin{array}{l}\text { Phenylcoumaran } \\
\text { benzylic ether } \\
\text { reductase homolog } \\
\text { TH6 }\end{array}$ & T. heterophylla \\
\hline & U11 & $38.66 / 42.35$ & $5.92 / 6.30$ & gi110816011 & 3 & 12.25 & $\begin{array}{l}\text { Phenylpropenal double- } \\
\text { bond reductase }\end{array}$ & P. taeda \\
\hline & U12 & $54.83 / 55.44$ & $6.11 / 5.25$ & gi126697262 & 8 & 27.93 & $\begin{array}{l}\text { Type } 2 \text { 1-hydroxy-2- } \\
\text { methyl-2-(E)-butenyl- } \\
\text { 4-phosphate reductase }\end{array}$ & P. taeda \\
\hline
\end{tabular}


Table 1 continued

\begin{tabular}{|c|c|c|c|c|c|c|c|c|}
\hline Metabolic group & Spot no. & $\begin{array}{l}\text { Theor./exp. } \\
\text { mass (kDa) }\end{array}$ & $\begin{array}{l}\text { Theor./ } \\
\text { exp. pI }\end{array}$ & $\begin{array}{l}\text { Accession } \\
\text { no. }\end{array}$ & NMP & $\mathrm{SC}(\%)$ & Description & Species \\
\hline \multirow[t]{5}{*}{ Protein stability } & U13 & $98.33 / 83.48$ & $5.94 / 5.97$ & gi327181869 & 1 & 2.53 & $\begin{array}{l}\text { ATP-dependent } \\
\text { chaperone clpb }\end{array}$ & $\begin{array}{l}\text { H. maritima } \\
\text { DSM } 10411\end{array}$ \\
\hline & U14 & $71.05 / 78.33$ & $5.13 / 5.12$ & gi3962377 & 1 & 4.00 & Heat shock protein 70 & A. thaliana \\
\hline & U15 & $1.531 / 28.49$ & $4.56 / 5.61$ & gi292630789 & 2 & 100 & $\begin{array}{l}\text { Putative heat shock } \\
\text { protein } 1\end{array}$ & P. menziesii \\
\hline & U16 & $71.01 / 72.89$ & $5.02 / 5.12$ & gi38325811 & 1 & 2.30 & Hsp70 protein & N. tabacum \\
\hline & U17 & $35.19 / 38.75$ & $5.86 / 5.19$ & gi326467059 & 2 & 8.11 & $\begin{array}{l}\text { oxygen-evolving } \\
\text { enhancer protein }\end{array}$ & L. chinensis \\
\hline \multirow[t]{3}{*}{$\begin{array}{l}\text { Amino acid and } \\
\text { nitrogen metabolism }\end{array}$} & D18 & $59.86 / 61.97$ & $5.56 / 5.30$ & gi223534807 & 3 & 11.05 & $\begin{array}{l}\text { Glutamyl-tRNA(Gln) } \\
\text { amidotransferase } \\
\text { subunit A }\end{array}$ & R. communis \\
\hline & D19 & $39.57 / 53.75$ & $6.21 / 6.38$ & gi404327 & 7 & 25.49 & $\begin{array}{l}\text { Glutamate-ammonia } \\
\text { ligase (GS1) }\end{array}$ & P. sylvestris \\
\hline & D20 & $37.23 / 45.36$ & $6.38 / 6.08$ & gi12802155 & 5 & 17.60 & Arginase & P. taeda \\
\hline Defense & U18 & $46.76 / 50.18$ & $5.89 / 5.64$ & gi294847377 & 1 & 2.76 & $\begin{array}{l}\text { Monodehydroascorbate } \\
\text { reductase }\end{array}$ & L. longiflorum \\
\hline
\end{tabular}

$D$ down-regulated proteins, $U$ up-regulated proteins, $N M P$ number of matched peptides, $S C$ sequence coverage

and energy metabolism group (spots. D1-D16, U1-U8). The second abundant proteins fall into secondary metabolism group (spots. D17, U9-U12). Proteins associated with protein stability attribute to the third abundant group which includes five up-regulated protein spots (spots. U13-U17). Subsequently are proteins belonging to amino acid and nitrogen metabolism group (spots. D18-D20). The least abundant group is associated with defense, however, only one protein identified (spots. U18). We found that more than half differently expressed proteins are related to photosynthesis and energy metabolism. Furthermore, most proteins involved in photosynthesis and amino acid metabolism were down-regulated and proteins involved in protein stability and defense were up-regulated. These suggest that SiAR stress interfered with the plant photosynthesis and primary metabolism. At the same time plant adaptive mechanisms against SiAR stresses were triggered to protect the plant from the further damage (Fig. 4).

Finally, it is interesting to note that Rubisco large subunit (D1-D8), ATPase beta subunit (U3-U5) and heat shock protein (HSP) 70 (U14, U16) were found in multiple spots with different MWs and pIs.

\section{Discussion}

Because of its adverse effects on forest health, acid rain has been regarded as a major stress for forest species and its negative effects have been studied extensively. Acid rain induces changes in the cellular biochemistry, physiology and ultrastructure of plants. For example, acid rain lead to decrease in photosynthetic rate, loss of nutrient from leaves, alterations of water balance and enzyme activities, and changes of pollen physiology and ultrastructure of chloroplasts and mitochondria (Bellani et al. 1997; Gabara et al. 2003; Van Huylenbroeck et al. 2000). In this work, SiAR stress-induced changes in the proteome of $P$. massoniana needles were analyzed after treatment with $\mathrm{SiAR}$ for 8 months. Out of more than 1,000 spots, 65 spots were identified to be differentially abundant, of these the identity of 28 proteins were established. Based on their physiological functions, proteins identified in the present work can be divided into five groups in correlation to their specific biological functions as described in "Results".

Suppression of photosynthetic enzymes in Calvin cycle caused by $\mathrm{SiAR}$

Eight (D1-D8) out of 16 down-regulated spots in the group belonging to photosynthesis and energy metabolism were identified. Transcriptome study revealed that $r b c L$ was down-regulated in Synechocystis sp. PCC 6803 under acid stress (Ohta et al. 2005). This suggests that the expression of $r b c L$ gene was suppressed at transcriptional level; hence the protein abundance was correspondingly reduced. In our study, a large number of proteins were found to be identical to Rubisco large subunit or were fragments of it, indicating the damaging effect of SiAR on the photosynthetic apparatus, which has also been reported in Agrostis tenuis under As-induced stress (Duquesnoy et al. 2009). Multiple spots for a single protein could also be due to post-translational modifications (Vener et al. 1998). Chemical modification of proteins during the preparation of samples might be another reason to cause proteolytic degradation and induce 
Fig. 3 Functional category distribution of 28 identified proteins under the treatment by simulated acid rain (SiAR)

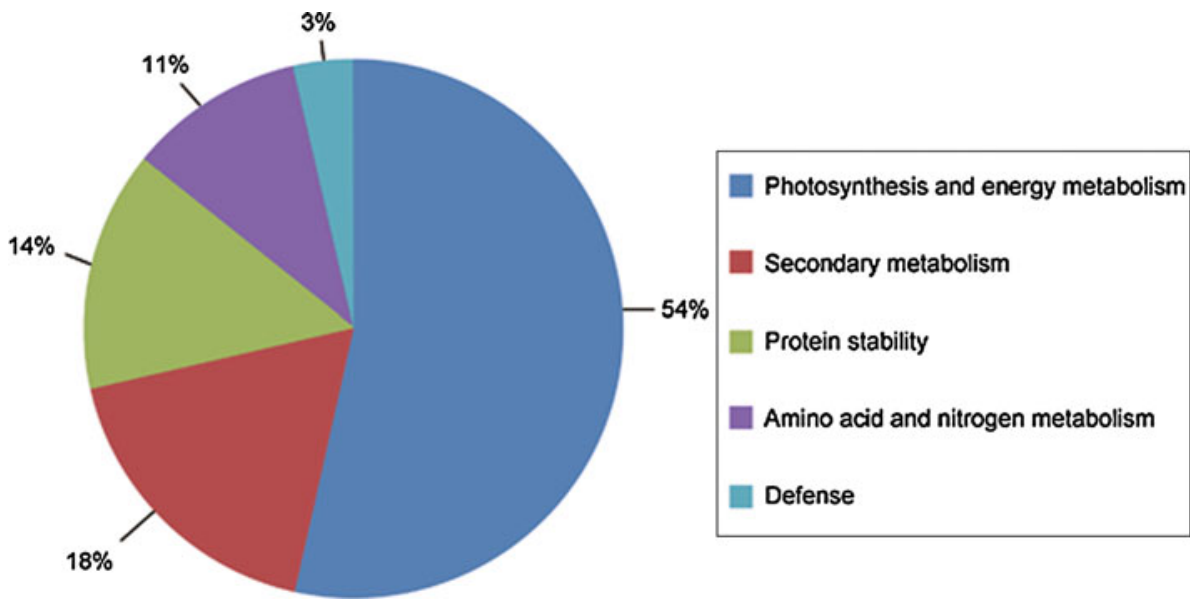

multiple spots on 2-DE gels. Fructose-bisphosphate aldolase (FBPase) is a very important enzyme in the Calvin cycle and plays a crucial role in plant response to some abiotic stimuli (Fan et al. 2009). In this study it was found that FBPase (spot D9) was down-regulated under SiAR, which was consistent with the previous observations on transcriptome level (Kim et al. 2009) in Arabidopsis. Sedoheptulose-1,7-bisphosphatase (SBPase) also plays an important role in the Calvin cycle. In this study, it was also found that SBPase (spot D10) was depressed after SiAR treatment as under drought (Wingler et al. 1999) and water (Bayramov et al. 2010) stresses, indicating that this enzyme is very sensitive to different abiotic stresses. A previous report identified that this enzyme plays a major role in $\mathrm{CO}_{2}$ fixation in $\mathrm{C}_{3}$ cycle and in plant growth as small reductions in the enzyme activity resulted in a decrease in $\mathrm{CO}_{2}$ fixation and growth (Raines 2011). Therefore, it should be postulated that suppression of the enzyme by SiAR would reduce photosynthetic efficiency in leaves of $P$. massoniana. Phosphoribulokinase (PRK) catalyzes the final step in the regeneration of ribulose-1,5-bisphosphate (RuBP) in the Calvin cycle. When $P$. massoniana was treated with SiAR in this study, the abundance of PRK (spot D11) was found declined. This is consistent with the report when plants suffered salt stress (Srivastava et al. 2008). However, only significant reduction of PRK had negative effects on photosynthesis and growth (Banks et al. 1999). On the basis of these results, it was postulated that the Calvin cycle could be very sensitive to SiAR stress and that SiAR could alter the abundance of photosynthetic enzymes to reduce the efficiency of photosynthesis in P. massoniana Lamb.

Disorders of energy-related metabolism

Sucrose-phosphatase catalyzes the final step in the pathway of sucrose biosynthesis. It was found that in this study sucrose-phosphatase (spot D12) was down-regulated under
SiAR stress. It was reported that a decreased sucrosephosphatase level in transgenic tobacco inhibits photosynthesis, alters carbohydrate partitioning, and reduces growth. The transgenic plant had strongly reduced levels of sucrose and hexoses (Chen et al. 2005). This may reflect that SiAR inhibits plant growth in more than one way: it not only reduces carbon fixation directly by down-regulating key enzymes in the Calvin cycle, but also affects carbohydrate transportation as sucrose is the main source for carbon export from source leaves to sink.

Our study also showed that glyceraldehyde-phosphate dehydrogenase (GAPDH, spot D13), pyruvate dehydrogenase E1 beta subunit isoform (spot D14), phosphoglycerate kinase (PGK, spot D15) and NADP-isocitrate dehydrogenase (NADP-ICDH, spot D16), which play important roles in primary energy metabolism, were down-regulated after treatment with SiAR. Down-regulation of PGK was also reported in mulberry (Thimmanaik et al. 2002) and maize (Hayano-Kanashiro et al. 2009) under drought stress, whereas up-regulation of $I C D H$, contrary to our report in this study, was found in maize (Liu et al. 2010). It was also reported that proteins involved in glycolysis, Krebs cycle and pentose phosphate pathway were down-regulated in root cells under saline stress (Jiang and Deyholos 2006) and plants reduce their energy consumption in order that the preserved energy can be used to protect the organs against ROS in vivo (Moller 2001). Our finding that downregulation of these four proteins under $\mathrm{SiAR}$ stress suggests that primary respiratory pathways were to some extent inhibited by SiAR and that plants reduced energy consumption under SiAR stress. It is widely known that SiAR treatment increases the level of ROS in plants. Plants would use the same strategy as under salt stress to detoxify ROS caused by SiAR.

The abundance of some proteins relative to energy metabolism was still found to be up-regulated. They are enoyl-ACP reductase (spot U1), ATP synthase beta subunit (spots. U2), ATPase beta subunit (spot U3-U5), granule- 
Fig. 4 Cell responses corresponding to differential abundance of proteins identified under the treatment by simulated acid rain (SiAR)

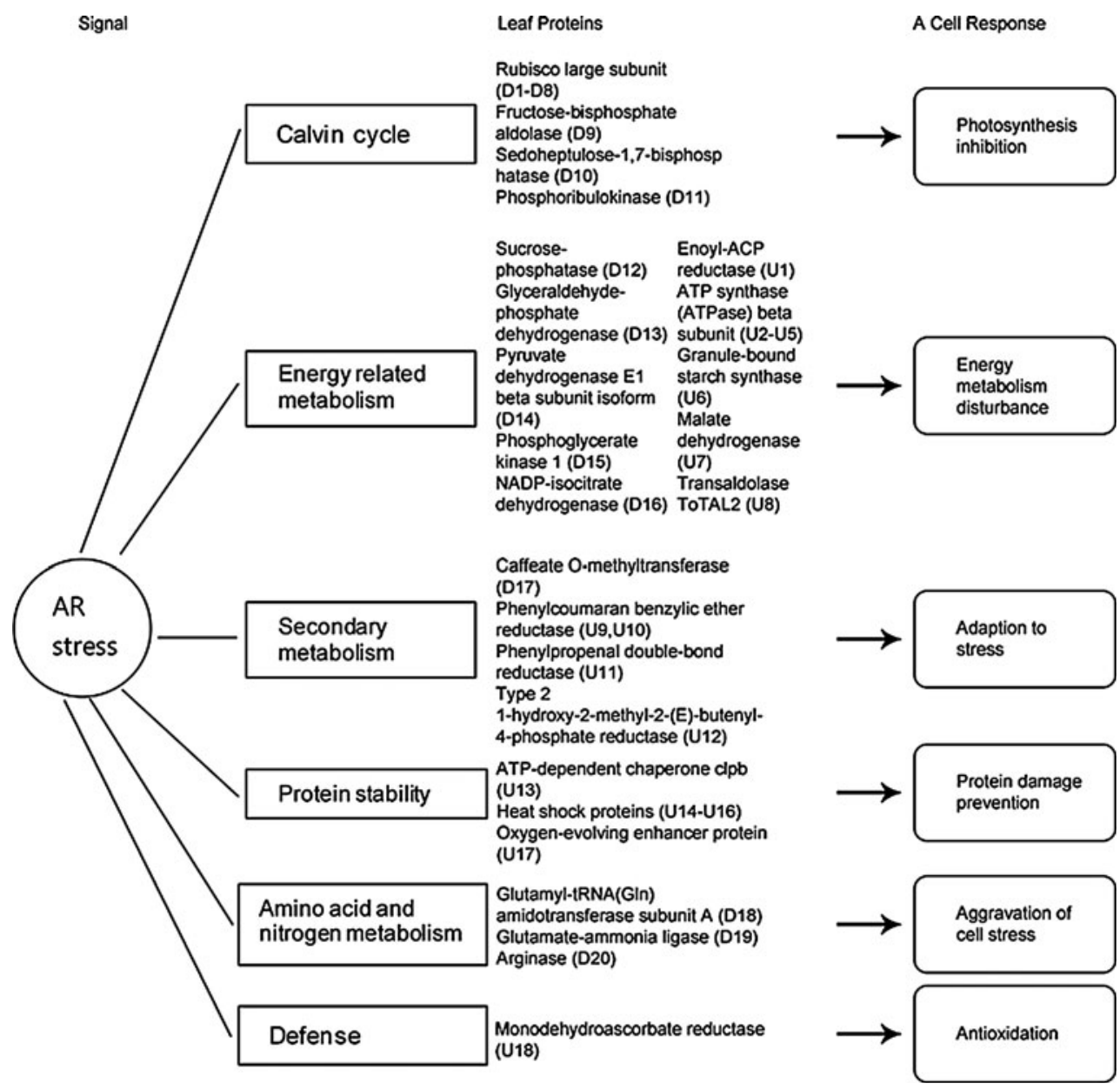

bound starch synthase (spot U6), malate dehydrogenase (MDH, spot U7) and transaldolase (spot U8). The specific roles of these enzymes in response to SiAR stress remain to be established. It should be pointed out that due to the depression of basic energy metabolism when suffering SiAR, the plant would need extra energy to sustain life by enhancing ATP synthase activity. Similar observations were also reported in wheat (Wang et al. 2008), rice (Kim et al. 2005) and potato (Aghaei et al. 2008) when plants met saline stress. So maintenance ATP-dependent abiotic tolerance by increasing the formation of ATP seems to be a common strategy that plants adopt to cope with abiotic stresses. MDH is an enzyme in the Krebs cycle that catalyzes the conversion of malate into oxaloacetate and vice versa. Over-expression of MDH increases the organic acid yield in plants and increases organic acid exudation to root surface to chelate and immobilize $\mathrm{Al}^{3+}$, which confers tolerance to $\mathrm{Al}$ in transgenic alfalfa in acid soil (Tesfaye et al. 2001). However, in most plant species, Al uptake is limited mainly to the root system. It is unlikely that upregulation of $\mathrm{MDH}$ in this study detoxifies $\mathrm{Al}$ in leaves as the endodermis possibly acts as a barrier and transport of Al from root to the shoot and leaves is generally small
(Vitorello et al. 2005). Although regulation mechanism of $\mathrm{MDH}$ in response to SiAR remains to be investigated, there was a report that $\mathrm{MDH}$ is a stress-responsive protein when plants were treated with cold (Hashimoto and Komatsu 2007).

It should be emphasized that metabolic pathways in cells are complex and interrelated. One protein can be involved in several pathways and be affected by many factors. Thus, some energy-related proteins were down-regulated, whereas some were up-regulated after SiAR treatment.

\section{Secondary metabolism-related proteins}

The minor group in response to SiAR stress is assigned to five proteins that are involved in secondary metabolism. They include caffeate $O$-methyltransferase (COMT, spot D17), phenylcoumaran benzylic ether reductase (PCBER, spots. U9, U10), phenylpropenal double-bond reductase (PPDBR, spot U11), type 2 1-hydroxy-2-methyl-2-(E)butenyl-4-phosphate reductase (HDR, spot U12). COMT acts in the phenylpropanoid pathway for biosynthesis of lignin (Humphreys and Chapple 2002). It was studied that in response to a water deficit, the abundance of COMT in 
plant leaves reduces and lignification decreases correspondently as an adaptive response to growth stunting. Reduced lignification of the elongation zone would be beneficial to the growth recovery upon release of stress (Vincent et al. 2005). PCBER is important in the biosynthesis of phenylpropanoid-derived compounds including several lignans which are widely known to act as antioxidants and can scavenge free radicals produced under stress. PCBER was reported to be up-regulated by abiotic stresses, such as drought (Pandey et al. 2008), excessive light (Nam et al. 2003), etc. In P. massoniana, COMT was downregulated and PCBER was up-regulated under SiAR stress as happened when plants were subjected to drought. These indicate that plants try to adjust to SiAR stress through signaling pathway that can be shared with other abiotic stresses. Further investigation on the functions of these proteins under SiAR stress would make up an interesting study.

\section{Protein stability-related proteins}

The third group in response to SiAR stress is linked to protein stability. It includes chaperone clpb (ClpB, spot U13), heat shock proteins (HSPs) (HSP70, spot U14 and U16; putative HSP1, spot U15) and oxygen evolving enhancer protein (OEE, spot U17). HSPs are known as stress proteins and they are considered an important part of the cellular stress response. Stressors such as heat, infection, inflammation, toxins, hypoxia, starvation and even exercise can result in the production of increased levels of HSPs (Wang et al. 2004). It is thought that an increase in protein damage can trigger this response. HSPs are also important in protein folding and ensuring the proper protein conformation. They play an important role in the prevention of protein aggregation. By stabilizing partially unfolded proteins, they help in the transport of proteins across various intracellular membranes (Hartl 1996; Wickner et al. 1999). ClpB is a molecular chaperon with ATPase activity. ClpB belongs to HSP100 subfamily of HSPs and also is called HSP100/ClpB protein. Our data demonstrated that the expression of these HSP was enhanced remarkably under SiAR stress, suggesting that SiAR increased a potential risk of protein misfolding and an active protein quality control system inside the cells was playing an important role in plant tolerance to SiAR stress. OEE is required for photosystem II assembly and stability. Previous report showed that expression of OEE was increased under salt stress in mangrove and rice (Abbasi and Komatsu 2004; Sugihara et al. 2000). Because OEE is easily removed from the PSII complex in the presence of $\mathrm{NaCl}$, over-expression of it might be needed to repair damage of photosynthetic apparatus. Further studies on drought stress in tall wheatgrass (Gazanchian et al. 2007) and on SiAR stress in our report revealed that up-regulation of OEE under various stresses is a common mechanism and it plays an important adaptive and protective role toward abiotic stresses. Anyway, it seems that plants have evolved protective mechanisms to perceive the acid stress signals or simply borrow other stress-responsive pathways and transmit them to the cellular machinery to activate adaptive responses.

Amino acid and nitrogen metabolism-related proteins

Amino acids play a critical role in protein synthesis and function in primary and secondary metabolism. SiAR also caused decreased expression of some amino acid metabolism-related enzymes, such as glutamyl-tRNA (Gln) amidotransferase subunit A (spot D18), glutamate-ammonia ligase (glutamine synthetase, GS, spot D19) and arginase (spot D20). Proline is thought to play an important role as an osmoregulatory solute subjected to abiotic stresses (Delauney and Verma 1993) and in stabilizing cellular structures as well as scavenging free radicals in plants (Hare and Cress 1997). Two groups of GS isoenzymes, plastidic (GS2) and cytosolic (GS1), have been identified in higher plants (McNally et al. 1983). It was reported that GS1 in the phloem plays a major role in controlling proline production. GS1 was, therefore, involved in stress regulatory networks as older leaves of transgenic tobacco lacking GS1 activity were more vulnerable to salt stress, showing wilting and bleaching phenotypes (Brugiere et al. 1999). GS2 also plays an important role in proline biosynthesis because proline accumulation during drought was substantially lower in GS2 mutant than in WT plants (Diaz et al. 2010). It was observed in this study that withered and yellow leaf needles of P. massoniana dropped off first after a long-running treatment with SiAR, suggesting that suppression of GS would exaggerate SiAR injury. By investigating the levels of proline at different leaf developmental stages and the manner of each member of the GS family under SiAR stress, it would give us a satisfactory answer. Arginase is involved in hydrolyzing arginine to produce urea and ornithine, the latter of which is a precursor for the synthesis of proline and polyamines (Zonia et al. 1995). Both proline and polyamines play important roles in the protection of plants against abiotic stresses. It was reported that arginase activity was induced in tomato leaves in response to wounding and treatment with jasmonic acid (JA, a potent signal for plant defense responses) through a pathway which were strictly dependent on an intact JA signal transduction (Chen et al. 2004). However, in our study Arginase was down-regulated under SiAR stress, indicating that there exists a different stress-responsive pathway from that by wounding and JA treatment in plants. Direct 
evidence that SiAR inhibits proline production was from the report on Hypogymnia (Kovacik et al. 2011). Combining our finding, it would be concluded that inhibition of GS and/or arginase by SiAR would be the cause for reduced production of proline. Detailed study on responsive mechanisms of proline synthesis-related enzymes to SiAR stress will provide a sound basis foundation to improve wood yield in our highly industrialized era.

\section{Anti-oxidation-related protein}

$\mathrm{H}_{2} \mathrm{O}_{2}$ is a strong oxidant that can initiate localized oxidative damage leading to disruption of metabolic function, damage of membrane and losses of cellular integrity at sites where it accumulates. $\mathrm{H}_{2} \mathrm{O}_{2}$ can also diffuse relatively long distances causing changes in the redox status of surrounding cells and tissues where at relatively low concentrations it initiates an antioxidative response (Foyer et al. 1997). By SiAR treatment, the level of $\mathrm{H}_{2} \mathrm{O}_{2}$ was increased in plant leaves and the ability of plants to overcome the effect of the SiAR stress may be related to the scavenging of stress-induced ROS, such as $\mathrm{H}_{2} \mathrm{O}_{2}$ (Van Huylenbroeck et al. 2000). Therefore, it is not surprising that enzymes related to anti-oxidation were induced under SiAR stress. In this study, however, we found that only one anti-oxidation enzyme, monodehydroascorbate reductase (MDHAR, spot U18), was up-regulated. In plants MDHAR is the enzymatic component involved in the regeneration of ascorbic acid which plays a critical role in the reduction of reactive oxygen. An increased expression of $M D H A R$ level in response to various oxidative stresses $\left(\mathrm{H}_{2} \mathrm{O}_{2}\right.$, salicylic acid, paraquat, ozone, high light, etc.) was also reported in Brassica campestris (Yoon et al. 2004) and pea (Leterrier et al. 2005). Up-regulation of MDHAR during SiAR stress indicates that plants use the same mechanism to scavenge ROS produced by SiAR as by other abiotic oxidative stresses and that MDHAR plays a key role in the production of antioxidants to minimize the cell damage in vivo.

\section{Conclusions}

In this study, the molecular response to SiAR stress was investigated at the protein level in P. massoniana. Sixtyfive differentially displayed protein spots were revealed, and 28 of them were further identified by MS analysis. These proteins were classified into five functional groups: photosynthesis and energy metabolism, secondary metabolism, protein stability, amino acid and nitrogen metabolism, and defense. It is the first report that four key enzymes involved in the Calvin cycle were down-regulated under long-term exposure to SiAR stress, suggesting that one important factor which resulted in biomass loss was due to reduction of carbon fixation. On the contrary to other abiotic stresses where proline acts as stress protectant, SiAR induced the suppression of proline-related synthetic pathways in this study. In particular, some stressrelated proteins for the synthesis of secondary metabolites were differentially changed in abundance under SiAR, implying their pivotal roles in stress adaptation or tolerance reactions in this forest plant. The functional determination of these proteins are expected to provide a deep understanding of the biochemical and physiological basis of acid rain stress responses in plants and to quicken the process of breeding new acid rain tolerant varieties of genetically modified forest trees. In all, our study, for the first time, demonstrates that long-term treatment by SiAR, resembling the effects of acid rain under natural state, induced different but profound cellular changes at the level of proteins in the forest plant from that of short-time SiARinduced stress.

Acknowledgments We thank Capital Normal University for supplying proteomic experimental platform and Xiamen University for supplying Plant materials. This work was supported by grants from National Natural Science Foundation of China (No. 30970250), China Postdoctoral Science Foundation to Dr. Wang and the Chang Jiang Scholarship Program. The funders had no role in study design, data collection and analysis, decision to publish, or preparation of the manuscript.

Open Access This article is distributed under the terms of the Creative Commons Attribution License which permits any use, distribution, and reproduction in any medium, provided the original author(s) and the source are credited.

\section{References}

Abbasi FM, Komatsu S (2004) A proteomic approach to analyze saltresponsive proteins in rice leaf sheath. Proteomics 4:2072-2081

Aghaei K, Ehsanpour AA, Komatsu S (2008) Proteome analysis of potato under salt stress. J Proteome Res 7:4858-4868

Banks FM, Driscoll SP, Parry MA, Lawlor DW, Knight JS, Gray JC, Paul MJ (1999) Decrease in phosphoribulokinase activity by antisense RNA in transgenic tobacco. relationship between photosynthesis, growth, and allocation at different nitrogen levels. Plant Physiol 119:1125-1136

Bayramov SM, Babayev HG, Khaligzade1 MN, Guliyev1 NM, Raines CA (2010) Effect of water stress on protein content of some Calvin cycle enzymes in different wheat genotypes. In: Proceedings of ANAS (Biological Sciences), vol 65. pp 106-111

Bellani LM, Rinallo C, Muccifora S, Gori P (1997) Effects of simulated acid rain on pollen physiology and ultrastructure in the apple. Environ Pollut 95:357-362

Brugiere N, Dubois F, Limami AM, Lelandais M, Roux Y, Sangwan RS, Hirel B (1999) Glutamine synthetase in the phloem plays a major role in controlling proline production. Plant Cell 11:1995-2012

Chen G, Gharib TG, Huang CC, Taylor JM, Misek DE, Kardia SL, Giordano TJ, Iannettoni MD, Orringer MB, Hanash SM, Beer DG (2002) Discordant protein and mRNA expression in lung adenocarcinomas. Mol Cell Proteomics 1:304-313 
Chen H, McCaig BC, Melotto M, He SY, Howe GA (2004) Regulation of plant arginase by wounding, jasmonate, and the phytotoxin coronatine. J Biol Chem 279:45998-46007

Chen S, Hajirezaei M, Peisker M, Tschiersch H, Sonnewald U, Bornke F (2005) Decreased sucrose-6-phosphate phosphatase level in transgenic tobacco inhibits photosynthesis, alters carbohydrate partitioning, and reduces growth. Planta 221:479-492

Delauney AJ, Verma DPS (1993) Proline biosynthesis and osmoregulation in plants. Plant $\mathrm{J}$ 4:215-223

Diaz P, Betti M, Sanchez DH, Udvardi MK, Monza J, Marquez AJ (2010) Deficiency in plastidic glutamine synthetase alters proline metabolism and transcriptomic response in Lotus japonicus under drought stress. New Phytol 188:1001-1013

Duquesnoy I, Goupil P, Nadaud I, Branlard G, Piquet-Pissalouxb A, Ledoigta G (2009) Identification of Agrostis tenuis leaf proteins in response to $\mathrm{As}(\mathrm{V})$ and $\mathrm{As}(\mathrm{III})$ induced stress using a proteomics approach. Plant Sci 176:206-213

Fan W, Zhang Z, Zhang Y (2009) Cloning and molecular characterization of fructose-1,6-bisphosphate aldolase gene regulated by high-salinity and drought in Sesuvium portulacastrum. Plant Cell Rep 28:975-984

Feng ZW (2000) Ecological effects and control strategies of acid deposition on ecosystems in China. Yunnan Environ Sci 19:1-6

Foyer CH, Lopez-Delgado H, Dat JF, Scott IM (1997) Hydrogen peroxide- and glutathione-associated mechanisms of acclamatory stress tolerance and signalling. Physiol Plant 100:241-254

Gabara B, Skłodowska M, Wyrwicka A, Glińska S, Gapińskab M (2003) Changes in the ultrastructure of chloroplasts and mitochondria and antioxidant enzyme activity in Lycopersicon esculentum Mill. leaves sprayed with acidrain. Plant Sci 164:507-516

Gazanchian A, Hajheidari M, Sima NK, Salekdeh GH (2007) Proteome response of Elymus elongatum to severe water stress and recovery. J Exp Bot 58:291-300

Gygi SP, Rochon Y, Franza BR, Aebersold R (1999) Correlation between protein and mRNA abundance in yeast. Mol Cell Biol 19:1720-1730

Hare PD, Cress WA (1997) Metabolic implications of stress-induced proline accumulation in plants. Plant Growth Regul 21:79-102

Hartl FU (1996) Molecular chaperones in cellular protein folding. Nature 381:571-579

Hashimoto M, Komatsu S (2007) Proteomic analysis of rice seedlings during cold stress. Proteomics 7:1293-1302

Hayano-Kanashiro C, Calderon-Vazquez C, Ibarra-Laclette E, Herrera-Estrella L, Simpson J (2009) Analysis of gene expression and physiological responses in three Mexican maize landraces under drought stress and recovery irrigation. PLoS ONE 4:e7531

Huang YZ, Li ZX, Li XD, Wu KT, Sun JZ (2006) Impact of simulated acid rain on growth and nutrient elements uptake by Eucalyptus urophylla and Pinus massoniana. Ecol Environ 15:331-336

Humphreys JM, Chapple C (2002) Rewriting the lignin roadmap. Curr Opin Plant Biol 5:224-229

Jiang Y, Deyholos MK (2006) Comprehensive transcriptional profiling of NaCl-stressed Arabidopsis roots reveals novel classes of responsive genes. BMC Plant Biol 6:25

Kim DW, Rakwal R, Agrawal GK, Jung YH, Shibato J, Jwa NS, Iwahashi Y, Iwahashi H, Kim DH, Shim IeS, Usui K (2005) A hydroponic rice seedling culture model system for investigating proteome of salt stress in rice leaf. Electrophoresis 26:4521-4539

Kim JK, Baek SA, Yoon S, Park HJ, Lee SC, Lee TS, Im KH (2009) Global analysis of gene expression upon acid treatment in Arabidopsis thaliana. Plant Pathol J 25:172-178

Kosova K, Vitamvas P, Prasil IT, Renaut J (2011) Plant proteome changes under abiotic stress-contribution of proteomics studies to understanding plant stress response. J Proteomics 74:1301-1322

Kovacik J, Klejdus B, Backor M, Stork F, Hedbavny J (2011) Physiological responses of root-less epiphytic plants to acid rain. Ecotoxicology 20:348-357

Leterrier M, Corpas FJ, Barroso JB, Sandalio LM, del Rio LA (2005) Peroxisomal monodehydroascorbate reductase. Genomic clone characterization and functional analysis under environmental stress conditions. Plant Physiol 138:2111-2123

Liu YH, Shi YS, Song YS, Wang TY, Li Y (2010) Characterization of a stress-induced NADP-isocitrate dehydrogenase gene in maize confers salt tolerance in Arabidopsis. J Plant Biol 13:107-112

MacKay VL, Li X, Flory MR, Turcott E, Law GL, Serikawa KA, Xu XL, Lee H, Goodlett DR, Aebersold R, Zhao LP, Morris DR (2004) Gene expression analyzed by high-resolution state array analysis and quantitative proteomics: response of yeast to mating pheromone. Mol Cell Proteomics 3:478-489

McNally SF, Hirel B, Gadal P, Mann AF, Stewart GR (1983) Glutamine synthetases of higher plants: evidence for a specific isoform content related to their possible physiological role and their compartmentation within the leaf. Plant Physiol 72:22-25

Moller IM (2001) Plant mitochondria and oxidative stress: electron transport, NADPH turnover, and metabolism of reactive oxygen species. Annu Rev Plant Physiol Plant Mol Biol 52:561-591

Nam MH, Heo EJ, Kim JY, Kim SI, Kwon KH, Seo JB, Kwon O, Yoo JS, Park YM (2003) Proteome analysis of the responses of Panax ginseng $\mathrm{C}$. A. Meyer leaves to high light: use of electrospray ionization quadrupole-time of flight mass spectrometry and expressed sequence tag data. Proteomics 3:2351-2367

Ohta H, Shibata Y, Haseyama Y, Yoshino Y, Suzuki T, Kagasawa T, Kamei A, Ikeuchi M, Enami I (2005) Identification of genes expressed in response to acid stress in Synechocystis sp. PCC 6803 using DNA microarrays. Photosynth Res 84:225-230

Pandey A, Chakraborty S, Datta A, Chakraborty N (2008) Proteomics approach to identify dehydration responsive nuclear proteins from chickpea (Cicer arietinum L.). Mol Cell Proteomics 7:88-107

Percy KE, Baker EA (1990) Effects of simulated acid rain on epicuticular wax production, morphology, chemical composition and on cuticular membrane thickness in two clones of Sitka spruce [Picea sitchensis (Bong.) Carr.]. New Phytol 116:79-87

Pradet-Balade B, Boulme F, Beug H, Mullner EW, Garcia-Sanz JA (2001) Translation control: bridging the gap between genomics and proteomics? Trends Biochem Sci 26:225-229

Raines CA (2011) Increasing photosynthetic carbon assimilation in C3 plants to improve crop yield: current and future strategies. Plant Physiol 155:36-42

Srivastava AK, Bhargava P, Thapar R, Rai LC (2008) Salinityinduced physiological and proteomic changes in Anabaena doliolum. Environ Exp Bot 64:49-57

Sugihara K, Hanagata N, Dubinsky Z, Baba S, Karube I (2000) Molecular characterization of cDNA encoding oxygen evolving enhancer protein 1 increased by salt treatment in the Mangrove Bruguiera gymnorrhiza. Plant Cell Physiol 41:1279-1285

Tamaoki M, Matsuyama T, Nakajima N, Aono M, Kubo A, Saji H (2004) A method for diagnosis of plant environmental stresses by gene expression profiling using a cDNA macroarray. Environ Pollut 131:137-145

Tesfaye M, Temple SJ, Allan DL, Vance CP, Samac DA (2001) Overexpression of malate dehydrogenase in transgenic alfalfa enhances organic acid synthesis and confers tolerance to aluminum. Plant Physiol 127:1836-1844

Thimmanaik S, Kumar SG, Kumari GJ NS, Sudhakar C (2002) Photosynthesis and the enzymes of photosynthetic carbon reduction cycle in mulberry during water stress and recovery. Photosynthetica 40:233-236 
Tian Q, Stepaniants SB, Mao M, Weng L, Feetham MC, Doyle MJ, Yi EC, Dai H, Thorsson V, Eng J, Goodlett D, Berger JP, Gunter B, Linseley PS, Stoughton RB, Aebersold R, Collins SJ, Hanlon WA, Hood LE (2004) Integrated genomic and proteomic analyses of gene expression in Mammalian cells. Mol Cell Proteomics 3:960-969

Van Huylenbroeck JM, Piqueras A, Debergh PC (2000) The evolution of photosynthetic capacity and the antioxidant enzymatic system during acclimatization of micropropagated Calathea plants. Plant Sci 155:59-66

van Wijk KJ (2001) Challenges and prospects of plant proteomics. Plant Physiol 126:501-508

Vener AV, Ohad I, Andersson B (1998) Protein phosphorylation and redox sensing in chloroplast thylakoids. Curr Opin Plant Biol $1: 217-223$

Vincent D, Lapierre C, Pollet B, Cornic G, Negroni L, Zivy M (2005) Water deficits affect caffeate $O$-methyltransferase, lignification, and related enzymes in maize leaves. A proteomic investigation. Plant Physiol 137:949-960

Vitorello VA, Capaldi FR, Stefanuto VA (2005) Recent advances in aluminum toxicity and resistance in higher plants. Braz J Plant Physiol 17:129-143

Wang W, Vinocur B, Shoseyov O, Altman A (2004) Role of plant heat-shock proteins and molecular chaperones in the abiotic stress response. Trends Plant Sci 9:244-252
Wang MC, Peng ZY, Li CL, Li F, Liu C, Xia GM (2008) Proteomic analysis on a high salt tolerance introgression strain of Triticum aestivum/Thinopyrum ponticum. Proteomics 8:1470-1489

Wang X, Kuang T, He Y (2010) Conservation between higher plants and the moss Physcomitrella patens in response to the phytohormone abscisic acid: a proteomics analysis. BMC Plant Biol 10:192

Wickner S, Maurizi MR, Gottesman S (1999) Posttranslational quality control: folding, refolding, and degrading proteins. Science 286:1888-1893

Wingler A, Quick WP, Bungard RA, Bailey KJ, Lea PJ, Leegood RC (1999) The role of photorespiration during drought stress: an analysis utilizing barley mutants with reduced activities of photorespiratory enzymes. Plant, Cell Environ 22:361-373

Yoon HS, Lee H, Lee IA, Kim KY, Jo J (2004) Molecular cloning of the monodehydroascorbate reductase gene from Brassica campestris and analysis of its mRNA level in response to oxidative stress. Biochim Biophys Acta 1658:181-186

Zivy M, de Vienne D (2000) Proteomics: a link between genomics, genetics and physiology. Plant Mol Biol 44:575-580

Zonia LE, Stebbins NE, Polacco JC (1995) Essential role of urease in germination of nitrogen-limited Arabidopsis thaliana seeds. Plant Physiol 107:1097-1103 